\title{
A LOCAL MIDWIFE OR A DOCTOR? TWO SYSTEMS OF KNOWLEDGE IN BIRTHING PRACTICES OF RUSSIAN OLD BELIEVERS
}

\author{
Natalia Dushakova \\ Research Fellow, PhD \\ Russian Presidential Academy of National Economy \\ and Public Administration, Russia \\ nataliadusacova@gmail.com
}

\begin{abstract}
The article explores complex relationships between traditional midwifery and medical institutions as two legitimate knowledge systems in the communities of Russian Old Believers in the Republic of Moldova and in Romania. It is aimed at discussing beliefs and practices around giving birth with the help of a local midwife from the same community, their transformation caused by the access to maternity hospitals as well as distribution of roles between a traditional birth attendant and a doctor. The article is based on oral narratives of Old Believers who used to be local midwives or gave birth to children with the help of such a specialist. The narratives were recorded by the author in 2008-2018.
\end{abstract}

Keywords: anthropology of birth, birthing practices, medical doctor, Old Believers, traditional birth attendant, traditional midwifery

\section{INTRODUCTION}

The first maternity hospitals in the rural areas of Moldova and Romania appeared in the early 1960s. From this time on, professional obstetric care started displacing the institution of traditional midwifery. Nevertheless, even despite the official struggle with rural midwives, they have enjoyed great authority for a long time: women often preferred to give birth with the help of a traditional birth attendant, rather than call a doctor or go to any medical institutions.

Since the 1970s, anthropologists have been studying the process of pregnancy and childbirth in the conditions of modern health care, comparing it with traditional birthing practices. In the works of American scholars, childbirth in official medical institutions is considered as a modified rite of passage. These topics became a part of a separate area of studies known as anthropology of birth. Ann Oakley gave consideration to the process of pregnancy and delivery in the 
context of medicalization of everyday life, when control over pregnancy and the birth of a child passed from the mother to doctors. Based on rich materials, she analyzed the issue of choosing between childbirth in hospitals and at home (Oakley 1984). Since the 1990s, Russian researchers also studied the practice of obstetric care in an urban environment (see, e.g., Belousova 2003) and the subculture of women giving birth (Shchepanskaia 1994). Yvonne Lefèber and Henk Voorhoever studied practices of traditional birth attendants in Africa, Asia, and Latin America, and revealed common practices and beliefs despite all the cultural differences. Scholars argue that it can be useful for obstetrics in other countries to learn from these specialists about their techniques in natural childbirth (Lefèber \& Voorhoever 1997).

Jeanmarie Rouhier-Willoughby pays attention to the two views of birth, which are "variously called the 'midwifery' model and the 'medical' model (Lichtman; Rothman) or the 'holistic' model and the 'technocratic' model (DavisFloyd)" (Rouhier-Willoughby 2003: 227). According to Brigitte Jordan, if there are several types of authoritative knowledge, which is the case with childbirth practices, one kind of knowledge often takes over. So when maternity hospitals spread, two institutions - traditional midwifery and modern obstetrics - exist as "equally legitimate parallel knowledge systems" and "people move easily between them, using them sequentially or in parallel fashion for particular purposes" (Jordan 1997: 56). "But frequently", she adds, "one kind of knowledge gains ascendance and legitimacy" (ibid.).

This article explores the way the two knowledge systems have been interacting in the communities of Russian Old Believers in the Republic of Moldova and in Romania since the middle of the twentieth century. Based on oral narratives of former local midwives and women who used the help of a traditional birth attendant from the same community, this article discusses beliefs and practices around giving birth before and after medical institutions were opened, as well as the distribution of roles between a local midwife and a doctor.

\section{THE FIELD AND SOURCES}

Fleeing from the persecution by the tsarist government and the official Orthodox Church, those who refused to follow church reforms (from 1782 called Old Believers) migrated to the confines of the Russian Empire. Establishing closed communities where they could reproduce pre-schism Orthodoxy, they still could not be fully separated from the world around them. Building their claim of true Orthodoxy on the refusal to change (Naumescu 2016: 3), Old Believers maintained their faith together with essential traditional practices. 
In the north-west Black Sea region Old Believers have settled since the early eighteenth century. One of the first Old Believer villages on this territory was Kunichnoe (Cunicea), situated in modern-day Moldova. Apart from that, up to the present Old Believers reside in other settlements in the Republic of Moldova (the villages of Pocrovca, Egorovca, Dobrudja Veche [Staraia Dobrudzha], the cities of Chisinau, Cahul, also Tiraspol and Bender in Transnistria, and others); Southern Ukraine (the villages of Staraia Nekrasovka, Novaia Nekrasovka, Muravlevka, Mirnoe, Zhebriiany (Primorskoe), the cities of Vilkovo, Izmail, Kiliia, and others); Romanian Dobrudja (the villages of Sarichioi, Jurilovca, Slava Rusa, Slava Cercheza, and others). (For general overviews of origin, history, and different aspects of Old Believers' culture in the region see, e.g., Crasovschi 2005; Ipatiov 2001; Litvina 2018; Prygarine 2004; Tudose 2015.)

I have conducted research in 17 settlements of the region since 2008 (see the map below, Fig. 1). For most of these localities the neighboring population includes, first of all, Moldovans, Ukrainians (in the Republic of Moldova and southern Ukraine) and Romanians (in Romanian Dobrudja). As for religious identities of the population living next to Old Believers, they are mostly Orthodox Christians of the main current called Nikonians, because they accepted the reforms introduced by Patriarch Nikon in the mid-seventeenth century. There are also a small number of Catholics, Protestants, and Jews. However, Old Believers themselves are not homogeneous either. In the north-west Black Sea region most Old Believers belong to the Belokrinitskaya Hierarchy, a smaller number of Old Believers are of Novozybkov Hierarchy: they are all popovtsy, which means priestly (with priests). In some localities there are Old Believers of both denominations (in the cities of Bender, Tiraspol). There are just a few localities with bezpopoutsy (priestless Old Believers), for instance, they reside in the city of Edinets in Moldova, but this paper is based on the data collected among the popoutsy.

Despite all the differences in local variants of cultural practices and beliefs, field studies among the Old Believers of the north-west Black Sea region demonstrate that local residents share general knowledge of ritual practices associated with preparing a future mother for the childbirth, the process of delivery, postpartum period, and care for the new mother and the baby (for more details on vernacular beliefs, prohibitions, and prescriptions concerning giving birth in Old Believer communities of Moldova and Romania see Dushakova 2018).

There are not many papers on birth rites of the Old Believers of the northwest Black Sea region. They are mostly either brief descriptions of birthing practices within general studies on Old Believer culture (Ipatiov 2001; Tudose 2015) or descriptions of field materials framed as common knowledge characteristic of a homogeneous tradition and with no metadata provided (Zakharch- 
enko 2004; Zakharchenko \& Petrova 2005; Stoianova \& Trotsyk 2006; Trotsyk 2005). More details on birthing practices of the Old Believers in Romania can be found in Aksiniia Krasovski's paper (Krasovski 2001) and Elena Arslanova's monograph (Arslanova 2010) devoted to life cycle rituals of the Old Believers in the Astrakhan' region, who migrated from Romanian Old Believer villages in 1947 and shared memories of their lives before settling in the USSR. In her studies of archaic peculiarities in the language and folk culture of Russian Old Believers in Romania, Anna Plotnikova pays attention to terminology and old ritual practices associated with birth and traditional midwifery (Plotnikova 2016: 40-50). She also describes a yearly celebration in honor of midwives in Russian villages in the Balkans as a tradition brought from the historical motherland (Plotnikova 2007). On the basis of materials collected among Nekrasov Cossacks - Old Believers who re-emigrated from Turkey to the Stavropol region of Russia - this holiday is described by Tatiana Vlaskina (2009). Peculiarities of birth rites and beliefs concerning midwifery among the Old Believers in Bulgaria have been studied by Elena Uzeneva (2008).

This paper is mostly based on the interviews with Russian Old Believers from the Republic of Moldova and Romania, using also the data from other settlements with Old Believer population for a broader picture and comparison. All the interviews were conducted in Russian, the native language of my interlocutors. On the basis of these materials an online database of folklore and ethnographic data was elaborated. Today the digital archive "Birth-Christening Rites of Old Believers of the North-west Black Sea Region" can be accessed online. ${ }^{1}$ The internet version of the database includes fragments of interviews in textual format accompanied by all the necessary metadata.

Although "the Soviet campaign against rural midwives began in the twenties and thirties and continued until the death of Stalin in 1953" and "after that for some time the persecution of midwives stopped" (Olson \& Adonieva 2016: 233; Ransel 2000), in the explored region of the former Moldovan SSR it was officially forbidden to call a local midwife for much longer, until the end of the 1970s. According to the memories of my interlocutors, in Romanian Old Believer villages the situation was similar: by the late $1970 \mathrm{~s}$, deliveries outside hospitals were already less common.

Currently, traditional obstetric care practices that have given way to qualified medical care are mainly preserved in the memory of the older generation. Therefore I mostly spoke with older women who themselves had acted as midwives or used their help at any stages of pregnancy, childbirth or postpartum care. The names of my interlocutors are encoded in the article, but I provide information on the locality and years of birth. 


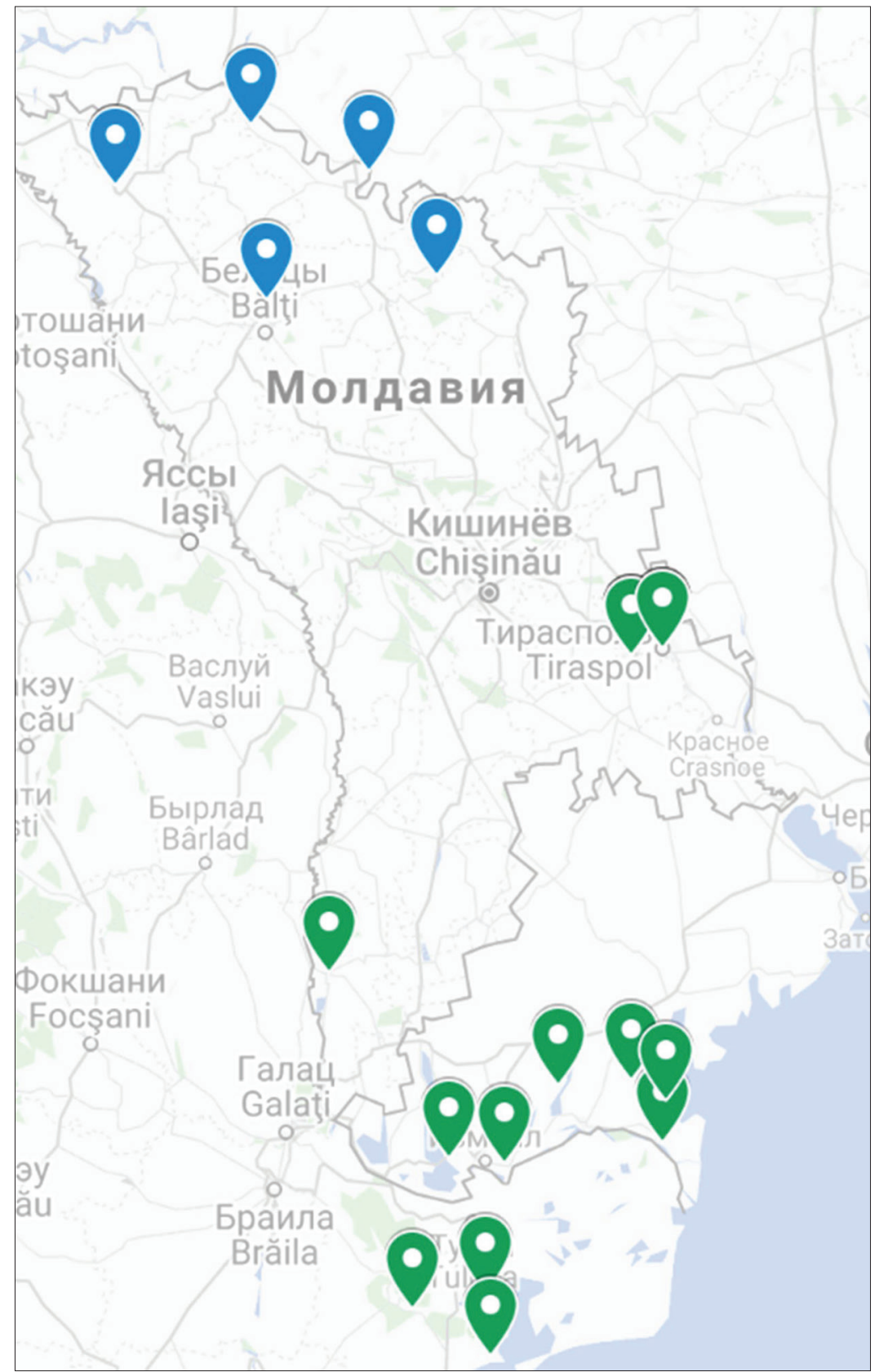

Figure 1. A map of research sites with Old Believer population in the north-west Black Sea region (Republic of Moldova, Romanian Dobrudja, and southern Ukraine), created by Natalia Dushakova based on Google Maps, 2020. 


\section{BEFORE MEDICAL INSTITUTIONS WERE OPENED: TWO PIECES OF EVIDENCE}

On research sites women remember giving birth in a bathhouse or in a separate room with the help of a local midwife. In the Republic of Moldova and in Romania, Old Believers called her babka, babushka, less often povitukha or povivukha. During the season of field work women often gave birth in the field. In such cases, they also turned to midwives:

Now in the hospital, and then babka tied the umbilical cord, yes, babka did everything. Then there was a babka, there were no doctors. There were doctors, they were somewhere, and our village - first of all, we didn't have a hospital, and second, there was nothing to get on, then there was no transport, and if you put a pregnant woman on a cart... She's working in the steppes, and she... suddenly felt unwell. One babka who knew in a moment took water there, and she brought [a child]. The baby was wrapped in her shawl. Then the child was wrapped in her clothes. This is how it used to be. ${ }^{2}$

As a rule, when the child was about to be born, the husband of the woman in labor or a neighbor called the midwife:

I gave birth to my first one in 1948. The first son was born. Well, I had time ... My husband went, brought a babka - a povitukha. Here. He brought a babka, this babka delivered my baby. Here. And the second girl was [delivered] by a babka, too, but the point was that it was too late.... Oh ... I came, but my husband was drunk, asleep. I knocked, knocked, knocked - I couldn't get through, I hardly reached out, it took him a while to open the door... And then I already had contractions. I asked him: "Call a babka!" And he was like... [laughing]: "What babka do you need? Nothing will happen to you!" He didn't want to go. And then he went. While that babka was coming, I - there was no wooden floor, there was dirt floor - I was on that... there was nothing to put on the floor, whatever. I was on the floor, on the dirt floor, on the damp one. Until that babka came, I froze completely. ${ }^{3}$

Sometimes a midwife delivered babies herself, but more often she was assisted by older female relatives or a neighbor of the woman in labor. The presence of children and men was strictly prohibited. 


\section{RURAL MIDWIFE: KNOWLEDGE AND FUNCTIONS}

According to my interlocutors, in the 1940s-1970s several local birth attendees acted at the same time at the research sites. Local residents often emphasized that not every woman could take this role: a widow or an older knowledgeable woman ("clean", in menopause status, see below) was preferable:

[The midwife herself taught a young one, didn't she?] Yes, yes. She was telling what and how to do all the things. [And who could be ... well, not everyone could be a midwife, right?] Well, of course, not anyone. She knew who could. Widows were often taken. [Were widows taken?] Yes, she had to be a widow. ${ }^{4}$

That could be wherever: in the yard, in the garden, and in the house - they could bring children anywhere. And in the bathhouse and around. And there was a special midwife like moaşa ["midwife" in Romanian - N.D.], such a midwife was called. She ... not every person could do these things, but old people did it, they served like doctors. ${ }^{5}$

Earlier, they taught these things, showed them, they knew how to raise the belly, they knew everything... There she put her hand and felt that it hurt here; she did it like a doctor. Or when someone broke an arm, or dislocated, or something, she would come and touch and say: "Hey, it's out of its place, and you should do it this way or that way." They bandaged that, did that, they were all like doctors, they understood everything; they had this talent from God. And they taught a lot. There was, let's say, there were many times when a babka had a younger daughter at home, and she taught her. There were many times that the mother died, and her daughter continued. A lot of this happened. But not any longer. ${ }^{6}$

As the interviews show, the knowledge was transferred either from mother to daughter, or from a knowledgeable woman ( $b a b k a$ ) to a younger woman suitable for this role. Apart from that, she had no professional training. The rules for choosing a midwife were based on special requirements for the purity of a woman, which in many Slavic traditions included a prohibition concerning the contact with death / the dead: midwives were strictly forbidden to wash the dead, "since the same gestures regarding a newborn would be fatal for them: death is contagious" (Kabakova 2001: 112-113). Contact with death among the Slavic people is considered as "a special case of ritual impurity" (Kabakova 2009a: 82). According to Elena Arslanova, Old Believers in Romania preferred a widow as a midwife; also her purity implied the absence of contact with the 
dead (Arslanova 2010: 35). However, in the village of Cunicea (Republic of Moldova), a midwife also washed the dead, and there were no beliefs recorded that this could have been prohibited. Currently, this woman no longer acts as a midwife, but continues to wash the dead, along with other washers.

Midwives knew ways of determining the gender of unborn babies. Besides a widely-spread practice to find out the baby's gender by the shape of the mother's abdomen, they also took into consideration the fetuses' behavior: "If it beats to the right, there will be a boy; if it beats to the left, a girl is to be expected" (recorded from former midwives in Old Believer villages in the Republic of Moldova). In Romanian Dobrudja traditional birth attendees predicted a child's future by birthday or the day of conception:

And babkas said ... that a baby was born on some day or on some holiday, and they read fortune: if the child was born, say, on Annunciation Day - on Annunciation a cuckoo doesn't build a nest - it's a great holiday, and they said if a baby was born on Annunciation Day, they would be happy, but if the conception took place on Annunciation, they would be unhappy. Do you understand? It means a cuckoo doesn't build a nest, but they conceived a baby on Annunciation. They would be unhappy. And there were different ones: they predicted fortune by holidays, by days. ${ }^{7}$

Some midwives in Romania had the gift of providence, the ability to read the fate of the child (Arslanova 2010: 36).

In helping a woman in labor, every midwife knew special massage techniques used to alleviate childbirth pain:

[When you were called to act as a midwife ... and it was bad for her, and she had a hard labor, suffered with childbirth, what did you do to help her?] [CEO:] You need to know the technique, work with your fingers, work with your fingers, you need to help her. ... And how we squeezed them with a towel! [MEA:] And with sheets, not just towels. [CEO:] A big towel, one woman on one side, the other - on the other side. ${ }^{8}$

[And how could a babka help? Was she massaging?] Well, help. She took a towel from here [in the abdomen - N.D.] and squeezed bit by bit, but as the head came out, she began to turn the head a little, and when the arms started to go out, she took them and ... took the baby out. ${ }^{9}$

[Did a babka have any special knowledge?] Nothing, absolutely not. It seemed she only massaged and that's all, nothing more. She fondled the belly a bit here, a bit there, rubbed her legs and hands. But there shouldn't have been earrings, no earrings, and there shouldn't have been any ring on the hand, or any bracelet. ${ }^{10}$ 
As an intermediary between a woman in labor and the higher powers, the birth attendee read special prayers during childbirth. At all the research sites, there is a widespread belief that in order to alleviate childbirth it is necessary to read the canon of the Virgin Fedorovskaya. Midwives accompanied every action by prayers to the Virgin Mother. It is worth mentioning that according to the local beliefs, the future mother had to pray herself, too: first of all, she had to read prayers to the Virgin Mother and Guardian Angel. To make the delivery easier, an icon lamp was lit, but the woman in labor was forbidden to touch it. Across the north-west Black Sea region Old Believers consider Fedorovskaya icon of the Mother of God to help during a difficult childbirth; this belief stands up to the present. In addition to the woman in labor and the midwife, all family members could pray to alleviate childbirth: "Mom told me who had been at home, everyone stood up and prayed ... [To have a good delivery?] Yes, yes, because a lot of women died in childbirth."11

The midwife could take on the functions of a priest and baptize the baby: if it was born weak, she could immerse the baby in the water so that it would not die unbaptized:

[MUN:] It was called immersed by the midwife. When a baby was brought, and it was weak, there ... [DVV:] Yes, yes, yes. [MUN:] ... looked like it would die, and she would do it right in the bucket, and would say: "In the name of the Father and the Son and the Holy Spirit". [DVV:] Yes, yes, and it was considered baptized. [MUN:] Yes, yes. [DVV:] Then they would go to the priest, and he would complete some prayers there, but he did not repeat it. He did not put the baby into the water, which means the baby was immersed in the name of the Holy Trinity. There it was. ${ }^{12}$

[So as the baby would not die unbaptized, could the midwife somehow immerse the baby into the water by herself?] [PSV:] Yes, yes, yes. Yes, I heard something like that too. [SAI:] Yes, yes, in a bucket. A new bucket of water and "I Believe" [a prayer; the canonic name of "I Believe" would be "Nicene Creed", the interlocutor names the prayer by its first words - N.D.], to read three times "I Believe", "Holy God", "I Believe"... Here Natasha was, the deceased sexton's wife, she went. She went, she immersed, it was called "immersed". [PSV:] Immersion. [SAI:] And then, if you didn't manage to baptize, you immersed the baby, and you buried it right after that. [Did they immerse babies three times?] Three times, yes. Natasha went, and such worthy women who prayed to God. Yes, she immersed. And if you didn't manage to immerse, then you didn't bury the baby. [But this way, can it be buried as if baptized?] Yes. Then the priest will add prayers, will read everything. As if baptized. [Did they 
call the baby half-baptized?] No, no. [And if the baby survived, then was it baptized later?] Yes. The priest would complete a bit there. Well, they didn't immerse it in the water, it counted. ${ }^{13}$

As noted by Galina Kabakova, "this precautionary measure is welcomed by both the family and the church, as the infant baptized by the midwife, even in the event of an early death, had the right to a Christian burial. If it survived, the priest completed the baptism" (Kabakova 2001: 117). The cited fragments of the interview show that the Old Believer priest did not immerse the infant for the second time.

The postnatal procedures also performed by the midwife included special actions with the umbilical cord and the afterbirth. The midwife cut the umbilical cord (mothers usually kept a part of it at home):

[And how did she [the midwife - N.D.] cut the umbilical cord?] Just with her scissors. ... Scissors used to sew, to cut the goods. ${ }^{14}$

[What did the midwife cut the umbilical cord with?] Thread. [Thread?] Yes. She would tighten the thread, and then it would fall off itself..$^{15}$

[And who cut the umbilical cord?] Babka. [And with what?] Well, what did she bandage with? I don't know what she was bandaging with. Then she specially wrapped the navel there. I remember my mother... Babushka Anisya delivered them all. So the navel had not fallen off yet, the baby's navel. I remember her tying it with a bandage, she spread some herbs there, put something... well, she knew that. ${ }^{16}$

After the delivery, it was important "to bury" the child's place (placenta, afterbirth) in the ground, to bury it symbolically, because among the Slavs the placenta was traditionally perceived as a twin of the child and/or mother (for more details see Kabakova 2009b: 200). According to Tatiana Listova, among the Russians "there was a belief that through the afterbirth, as well as through the umbilical cord, it is possible to harm a woman in labor and the child. Even the unintentional destruction of it could have a detrimental effect. Therefore, the midwife had to bury the placenta so that no one, neither a person nor an animal, could reach it" (Listova 1997: 508). My interlocutors in the Republic of Moldova and in Romania remember that local midwives buried placenta in the places where no one walked.

Another important function of the midwife was postnatal care of the mother and the newborn. It usually lasted for eight days (less often - three days) and included bathing, rubbing, and, if necessary, treating the mother and the baby: 
Right after the delivery the new mother was given a big glass of wine so that she replenished with blood. ... And after that the babka [took the new mother] to the bath house, and she rubbed her, she came on eight days and washed her in the bathhouse. Eight consecutive days she washed her and her baby. ${ }^{17}$

There were herbs there, in the cast iron those herbs were boiled, one put those herbs under the baby's head, here one took water and poured it from a mug, washed the baby... The babka bathed the baby with a prayer. ${ }^{18}$

According to Alla Galkina and Aleksandr Prigarin, in the Odessa region (southern Ukraine) the babka massaged the baby right after birth. Every day (for three days) she came to the new mother, washed her, rubbed her in the bath, lifted her stomach, looked after the baby (Galkina \& Prigarin 2014: 589).

The responsibilities of the midwife were considered to end with "washing the hands". Local women usually called this rite "seeing the babka off". Memories of this practice were recorded in Sarichioi (Romania):

That babka is then taken to the bathhouse, and she rubs the woman, the new mother. [After giving birth?] Yes, yes, yes. And she would wash the baby and rub it as she knew. And three baths had to be done. And then the babka was given soap, a bar of soap was given, and a towel was given to her. She was given a towel and soap. And money ... [Was it like a gift to her?] Yes. This was when she finished that... When the babka was given water on her hands, and she wiped her hands, washed them and wiped them with the towel you gave her, and the soap was the one you gave her. ${ }^{19}$

Describing the traditions concerning childbirth in Russia (Tambov region), David Ransel noted that "the ceremony of 'washing the hands' and paying the midwife ... and invocations of God's help, together with the control that the village midwife and members of the family exercised, free of the influence of outsiders, endowed the birthing process with a protective intimacy" (Ransel 2000: 128).

It is noteworthy that even after performing the rites of "washing the hands" / "seeing the babka off" new mothers could still address the midwife if they needed help. For instance, in case a woman had no milk to breastfeed her baby, she sought help from the traditional birth attendee. Rural midwives also treated the mother and the baby for the evil eye, prepared evil eye amulets for pregnant women, treated babies for slight illnesses using medicinal herbs and prayers.

Field materials show that after delivering a baby and providing postnatal care, the midwife had to undergo ritual purification. The new mother and the 
baby had to go through it, and all those who could be present at the childbirth or visited the woman before the baby was baptized - during that period the mother and the newborn were considered impure. The midwife was also among these people: local women remembered that after attending a childbirth the babka had to take a prayer from the priest, it was called the purification prayer. The priest would say this prayer. Here I would like to draw attention to the fact that the midwife could take a prayer on the third or eighth day after childbirth, when she had finished the postnatal care of the mother and the newborn, while the woman who gave birth usually went to church with the baby on the fortieth day. Along with the purification prayer, it is called the fortieth prayer. In rare cases, the midwife accompanied the new mother to the church, after having performed the rite of purification.

To sum up, the local midwife's knowledge went far beyond birthing procedures. She acted as a ritual specialist, whom the villagers addressed during the rites of passage (not only birthing, but also funeral rites, as field materials demonstrate), and also performed a number of traditional healer functions. It was in her power to ensure a baby's entrance into the community. In emergency cases, the midwife could take on the functions of a priest: she said prayers to ease pain during labor, and baptized infants born weak to prevent the death of unbaptized children.

\section{EXPRESSING GRATITUDE AND HONORING MIDWIVES}

Traditionally money was not paid for help during the delivery. However, according to Alla Galkina and Aleksandr Prigarin, in Odessa region a local midwife had been given presents and money since the 1930s. Old Believers thanked a babka with soap, a kalach (traditional white ring-shaped bread) and a kerchief; at christening she was given several kalaches, a kerchief, and length of dress fabric (Galkina \& Prigarin 2014: 590). In Romania midwives were presented with money, soap, bread, salt, a piece of fabric, in the village of Carcaliu also matches. The gifts symbolized wishes of purity and well-being to the midwife (Plotnikova 2016: 42-43). As mentioned by Galina Kabakova, until the midwife was fully rewarded, the child symbolically belonged to her (Kabakova 2009a: 84). There was a special day devoted to midwives in the folk calendar, when women would visit the village midwife and bring her gifts, known among Russians in many regions. It was called babii kashki, because the midwife (babka) prepared porridge (kasha) as a treat for her guests. There was also another local variant of the celebration: women prepared porridge and took it together with other presents to the village midwife. The Old Believers of Romanian Dobrudja had 
this celebration on the 14th of January (the day of St. Basil the Great) or during Maslenitsa festival in the villages of the Danube delta (Plotnikova 2016: 46-47). In Aksiniia Krasovski's description of this tradition among the Old Believers in Romania, there is a clarification that women gathered at the midwife's for the first day of St. Basil the Great or Maslenitsa after childbirth (Krasovski 2001: 252). The Old Believers of Bulgaria celebrated the holiday in honor of the midwives on the 14th of January: on this day, all new mothers visited the midwives who had delivered their children, brought them gifts, had a feast (Uzeneva 2008: 177). When describing this holiday among the Old Believers of Romania, Anna Plotnikova pointed out that at the time of her research (in 2006-2013) it only lived in people's memories thanks to older relatives' stories. In the Danube delta, at present the celebration is settled for the midwives' name days (Plotnikova 2016: 49-50). My interlocutors in Moldova and Romanian Dobrudja remembered neither the name of the holiday babii kashki nor such a celebration on St. Basil's Day or Maslenitsa. However, almost all local women told me about visiting village midwives who had delivered their children and giving them presents for their birthdays, sometimes also for children's birthdays (for instance, in Old Believer villages in Moldova).

\section{LOCAL MIDWIVES AND DOCTORS}

In the 1960 s, maternity hospitals appeared at the research sites, and qualified medical care became available. However, the institution of traditional midwives did not recede into the past, but entered into interaction with professional obstetrics. This phenomenon was widespread, characteristic not only for Moldova and Romania. Svetlana Adonieva and Lora Olson paid attention to the fact that "women perceived maternity hospitals as alienating, depersonalizing institutions ... recognizing the need for medical intervention, they continued to seek help from older relatives in search of knowledge about caring for themselves and the baby. In the village, women could go to local old women known for their knowledge" (Olson \& Adonieva 2016: 233). In Old Believers' villages, women had greater confidence in local ritual specialists, since they not only knew the techniques of relieving birth pain, but also knew what prayers should be said during childbirth, they could immerse the baby if necessary, etc., in other words, they knew "tradition".

Recognizing the achievements of medicine, women were not willing to refuse the services of midwives, so they turned to both doctors and traditional birth attendants at the same time: 
There was a hospital, a babka and a doctor. And the babka ... [What did she do?] The babka delivered the baby. And the doctor treated after that, when ... if the child was sick. There were babkas, I witnessed babkas. I brought a girl, in the sixty-third, in January, Tatiana ... [And what did babkas do? They just... did they come when the birth began? Or how?] Yes. And there they were, they sat there - in the hospital, where they gave birth. The babka slept there, and the doctor in this room. ${ }^{20}$

I was a midwife, but I called a doctor. And, on the contrary, they would call a rural midwife to the doctor. A woman came from Poiana the village next to Cunicea - N.D.], and G.I. was absent, she had lunch, one had to go as far as to the forest. And the dentist we had was a man. So what? A woman will give birth. Girls... There were girls there, nurses on duty and junior nurses. All were girls. And he says this: "Babushka E., go to your maternity hospital." There was no junior nurse on duty at that time; there were only two nurses there. Only two were there, and they fell ill, and there was no duty and there were no nurses. And we were, even until then. And there was no junior nurse at all. I went. I went to $S$. and said: "I need help, because," I say, "I ..." And he went out, standing on the threshold, looking at me like that: "Aunt E., honestly, I don't know. Well, forgive me, I am a dentist, we didn't practice this, they didn't take us, they didn't show us anything. I honestly don't know." I say: "As you wish, I will not do it alone. The woman is already giving birth, the waters have already broken." I ran; I didn't talk to him for a long time, because it had already... and he came. And he put on a medical gown and said: "Aunt E., if you know, understand, do it. I will only if, God forbid, I can help you: give injections, something else. And I'm there. What should I do?" And so he stood before me: "What should I do there?" On the table there... And I say: "You stand near me, what I tell you, you will give me." 1

The last fragment of the interview shows that the midwife could act as an obstetrician-gynecologist when state medical institutions were already operating in the villages. In the above interview, the rural midwife performs delivery in a hospital with a dentist at a time when there are no maternity nurses at work. On the other hand, traditional birth attendees recognize the need for more qualified medical care. It can be seen that at this time two institutions traditional midwifery and qualified obstetrics - exist as parallel systems of knowledge and people use both or one of them according to their needs. It results in a gradual distribution of duties: childbirth is attended by trained medical personnel, and the care of a new mother and the baby, as well as the treatment of the newborn, remains the responsibility of the midwife (in rare cases, it is 
the other way round: the midwife delivers the baby and then the doctor treats the woman and the baby, see the example above).

A similar practice of childbirth with the help of traditional midwives and doctors was observed by Elena Arslanova among the Old Believers of the Astrakhan region, who re-emigrated from Romania:

Women who gave birth were cared for by obstetricians and midwives, each according to their own knowledge: "the doctor delivered the baby, the midwife took care of it"... The tasks of the obstetrician included delivering the baby, taking its measurements, weighing it. In the postnatal period, she visited the new mother in order to check whether the navel was not wet. The midwife remained to perform postpartum procedures. (Arslanova 2010: 39)

It is significant that the representatives of official medicine at the research sites did not oppose such a distribution of roles. It was only forbidden to use the services of a midwife without a doctor during childbirth. The struggle against traditional midwifery took place within the framework of the state reorganization of obstetric care practices, which began in Russia in the 1920s, with the foundation of the Department for the Protection of Motherhood and Infancy under the People's Commissariat of State Charity. Nevertheless, during the implementation of this state program, there were no medical facilities at the research sites: women had to call obstetricians to their places or go to the nearest city maternity hospitals. As a result, women in labor did not refuse the help of the local midwives, but concealed that fact:

And she [the babka - N.D.] delivered my baby. She was born to me very big. And then babushkas were forbidden to come. They wanted us to call... doctors, and ... an obstetrician. And we did not have a hospital yet. And then, like, well, a timber house there was, they made one room, and then when they were already there, when they came to me, two of them - like a maternity nurse and one more. They looked and said: "It is not true that you..." I said that I gave birth alone, there was no babushka. And she said: "It's not true, you could not have given birth to her alone. She is so heavy, she weighs," she says, "more than four kilograms. You couldn't have given birth to her alone." 22

It is interesting that in some interviews, local residents not only compared the traditional birth attendee with the doctor, but also called the obstetrician babka. When maternity hospitals opened in the villages, some rural midwives worked there as nurses or junior nurses. In Cunicea (the Republic of Moldova), one of the former midwives told me how her daughter gave birth to a child: they did 
not have time to go to the hospital, therefore the mother (midwife) delivered the baby at home, and then drove the woman to the hospital:

I arrived with her at four in the morning, brought her already. They said: "And who helped to deliver the baby?" I said: "I did!" They came talking. I said: "Girls, faster, the afterbirth did not come out, nothing ..." - "And who," they returned once again, "who helped to deliver the baby?" I said: "I did." - "And who are you?" - "Mother." - "Giiiirls!" The doctor asked this: "Girls, let's get a stretcher faster." They carried her, and at home I prepared a bag for them. What you needed, everything, everything, everything. When I go, I go straight to the hospital - I'm a doctor. And they: "Where are you going?" I say: "Take this bag, have breakfast there. You do everything, then," I say, "have breakfast." And she, the nurse, says: "Could you even also prepare a bag?" I say: "I know, - I say, - I know this. I was, worked in our hospital." Then I began to talk with them. "Well," she says, "that's something! The mother [of the woman in labor - N.D.] delivered the baby and brought, - she says, - breakfast for us. ${ }^{{ }^{23}}$

It can be seen from the above fragment of the biographical narrative that a woman who was a rural midwife began working as a junior nurse in the maternity hospital in the 1960s. She considers herself a doctor, i.e., fits into the system of official medicine. Since the $1980 \mathrm{~s}$, the ban on traditional midwifery no longer existed, so home births stopped being hidden. In addition, in the last interview, the form of gratitude of the medical staff is noteworthy: nurses, like the village midwife, were offered food and refreshments as a form of gratitude. My interlocutors often pointed to this analogy themselves.

Let us compare the previous narrative with local women's memories regarding meeting and seeing off the midwife after childbirth:

There was a babka, when she came, a samovar was waiting for her, and with tea, warm wine, and this was for the babka, the treat was for the babka, yes. And she, when it was late or night, or cold, or rain, she did not go home, stayed. And these eight days, although she went home, she came every day. They said: "Today at three o'clock we will heat the bath [bania]." She already knew, she already went at two o'clock. ${ }^{24}$

Right after delivery. The babka washed herself, her hands, the baby was laid, the new mother sat. Here the relatives laid the table, treated her, and the babka was paid, they gave her a present that they had bought. It's like now in the maternity hospital: all the same they give these obstetricians gifts. $^{25}$ 
It should be noted that an important difference between the traditional practice of obstetric care and that of the medical institutions was the connection between the midwife and the children she had delivered. At my research sites in Romania and the Republic of Moldova local women pointed to the connection between a midwife and a child quite literally: it was believed that the midwife brought the baby, therefore she was a part of the future life of the child. Midwives were treated as relatives, they were invited to celebrate children's birthdays; it was customary to give presents to the midwives not only after the childbirth, but also as the child grew older. Traditional birth attendees were thanked not just for technical assistance, but also for the cultural role (Belousova 2003: 365).

The relationship between the doctor who delivered the baby in the hospital and the newborn looks less deep than that between the midwife and the child. However, the situation is not so simple either. Comparing the functions of "a midwife in traditional culture and the functions of an obstetrician-gynecologist in modern urban culture", Ekaterina Belousova argues that doctors feel their important roles in the complex process of giving birth, which requires from them much more than just medical assistance. As "children of their culture", doctors realize key cultural concepts encoding childbirth. Medics actively use "folk methods" in their practice, take into consideration popular beliefs concerning childbirth (for instance, determining the sex of the future child, programming his or her physical and mental development, washing and dressing the baby, constructing norms on how long the new mother has to breastfeed the baby, when the child has to start speaking). Ekaterina Belousova concludes that a typological comparison of actions and statements of doctors with traditional forms of authoritative knowledge suggests that the sociocultural aspect of these actions and statements can be considered even more important than the medical one (Belousova 2003: 358-367).

However, a doctor's help is often not enough: in the villages with Old Believer population, "even today, when women deliver in hospitals, they ask that an older woman come to the bania to wash and massage mother and the newborn" (Crasovschi 2005: 42). This practice is still spread throughout the region (Romania, Moldova, southern Ukraine).

\section{CONCLUSION}

When official medicine began to spread, the institution of midwives was not marginalized, but started competing with it. Many women preferred birthing at home to doing it in rural hospitals. Local midwives not only knew how to relieve physical pain, but remembered appropriate prayers, could serve as priests if 
a child was born weak and needed to be baptized as quickly as possible. When the authorities prohibited the practice of traditional midwifery, local women did not abandon it - they started concealing the fact of giving birth with the help of ritual specialists. But eventually, traditional midwifery, which initially enjoyed great authority in comparison with skilled obstetrics, entered into dialogue with it. This led to a form of coexistence of two legitimate systems of knowledge, in which, at first glance, each of them had a specific role. Women in labor addressed both traditional midwives they trusted and doctors who knew modern medical science. A closer look reveals that it is impossible to draw a clear line between the two systems and institutions (for example, rural midwives worked in hospitals and delivered babies together with doctors), even though the knowledge of a traditional midwife was not limited to birthing practices and she performed many more functions than an obstetrician. Nowadays women prefer official medicine and equipped hospitals. However, long-term parallel use of the services of obstetricians and ritual specialists is still reflected in modern birthing practices in Old Believer communities (transferring interaction models with a midwife to communication with a doctor; treatment of a mother and a newborn for slight illnesses by the former rural midwife, who can also cure the evil eye or share methods of protection from this misfortune). As for obstetricians in modern medical institutions, they also use vernacular knowledge and do more than just provide women in labor with medical assistance.

\section{ACKNOWLEDGEMENTS}

The article was written on the basis of the RANEPA state assignment research program.

\section{NOTES}

1 Online database of folklore and ethnographic data, "Birth-Christening Rites of Old Believers of the North-west Black Sea Region", available at http://eurasianphonology. info/static/childbirth/childbirth_index_location.html (last accessed on 21 September 2020). The elaboration of the digital archive was funded by RFBR, project number 16-36-60024 mol_a_dk.

${ }^{2}$ Recorded in the village of Jurilovca, Romania, from REI, born in 1953.

3 Recorded in the village of Dobrudja Veche, Republic of Moldova, from IER, born in 1926. 
4 Recorded in the village of Dobrudja Veche, Republic of Moldova, from IER, born in 1926.

5 Recorded in the village of Jurilovca, Romania, from REI, born in 1953.

6 Recorded in the village of Jurilovca, Romania, from REI, born in 1953.

7 Recorded in the village of Jurilovca, Romania, from REI, born in 1953.

8 Recorded in the village of Cunicea, Republic of Moldova, from CEO, born in 1940, and MEA, born in 1951.

9 Recorded in the village of Cunicea, Republic of Moldova, from CAE, born in 1931.

${ }^{10}$ Recorded in the village of Dobrudja Veche, Republic of Moldova, from IER, born in 1926.

${ }^{11}$ Recorded in the village of Dobrudja Veche, Republic of Moldova, from HTA, born in 1950.

${ }^{12}$ Recorded in the village of Sarichioi, Romania, from MUN, born in 1942, and DVV, born in 1948.

${ }^{13}$ Recorded in the village of Cunicea, Republic of Moldova, from SAI, born in 1947, and PSV, born in 1951.

${ }^{14}$ Recorded in the village of Jurilovca, Romania, from REI, born in 1953.

${ }^{15}$ Recorded in the village of Cunicea, Republic of Moldova, from CAE, born in 1931.

${ }^{16}$ Recorded in the village of Cunicea, Republic of Moldova, from SAI, born in 1947.

${ }^{17}$ Recorded in the village of Jurilovca, Romania, from REI, born in 1953.

${ }^{18}$ Recorded in the village of Cunicea, Republic of Moldova, from SAI, born in 1947.

${ }^{19}$ Recorded in the village of Sarichioi, Romania, from SPI, born in 1953.

${ }^{20}$ Recorded in the village of Sarichioi, Romania, from MH, born in 1942.

${ }^{21}$ Recorded in the village of Cunicea, Republic of Moldova, from CEO, born in 1940.

${ }^{22}$ Recorded in the village of Cunicea, Republic of Moldova, from CAE, born in 1931.

${ }^{23}$ Recorded in the village of Cunicea, Republic of Moldova, from CEO, born in 1940.

${ }^{24}$ Recorded in the village of Jurilovca, Romania, from REI, born in 1953.

${ }^{25}$ Recorded in the village of Cunicea, Republic of Moldova, from SAI, born in 1947. 


\section{REFERENCES}

Arslanova, Elena 2010. Obriady zhiznennogo tsikla staroobriadtsev-lipovan Astrakhanskoi oblasti (rodil'no-krestil'nye i pokhoronno-pominal'nye). [Rites of the Life Cycle of Old Believers-Lipovans of Astrakhan Oblast' (Birth-Christening and Funeral).] Monograph. Astrakhan: Izdatel'stvo Sorokin R.V. Available at http://russkayasvyaz.ru/wp-content/uploads/2015/10/Книга-Пауновой.pdf, last accessed on 22 September 2020.

Belousova, Ekaterina 2003. Rodil'nyi obriad. [Birth Rite.] In: Aleksandr Belousov \& Inna Veselova \& Sergei Nekliudov (eds.) Sovremennyi gorodskoi fol'klor. Moscow: Rossiiskii gosudarstvennyi gumanitarnyi universitet, pp. 339-369.

Crasovschi, Axinia 2005. Russian Old Believers (Lipovans) in Romania: Cultural Values and Symbols. In: Irina Vainovski-Mihai (ed.) New Europe College Yearbook 20012002. Bucharest: New Europe College, pp. 17-59. Available at http://docplayer. fr/2290170-New-europe-college-yearbook-2001-2002.html, last accessed on 21 September 2020.

Dushakova, Natalia 2018. Rodil'naia obriadnost' staroobriadtsev Severo-Zapadnogo Prichernomor'ia: aktual'nye vernakuliarnye predstavleniia i praktiki. [Birth Rites among the Old Believers of the North-West Black Sea Region: Current Vernacular Beliefs.] Etnograficheskoe obozrenie, No. 3, pp. 133-150. https://doi. org/10.7868/S0869541518030107.

Galkina, Alla \& Prigarin, Aleksandr 2014. Russkie. [Russians.] In: Anton Kisse \& Aleksandr Prigarin \& Vladimir Stanko (ed.) Budzhak: istoriko-etnograficheskie ocherki narodov iugo-zapadnykh raionov Odesshchiny. [Budzhak: Historical and Ethnographic Essays on the Peoples of South-West Odessa Region.] Odessa: PostScriptUm - SMIL, pp. 555-602. Available at https://yadi.sk/i/ QGt1nLT1xP3bQ, last accessed on 22 September 2020.

Ipatiov, Filip 2001. Ruşii-lipoveni din România: Studiu de geografie umană. [Russian Lipovans from Romania: Studies in Human Geography.] Cluj-Napoca: Editura Presa Universitară Clujeană.

Jordan, Brigitte 1997. Authoritative Knowledge and Its Construction. In: Robbie E. DavisFloyd \& Carolyn F. Sargent (eds.) Childbirth and Authoritative Knowledge: Crosscultural Perspectives. Berkeley \& Los Angeles \& London: University of California Press, pp. 55-79. https://doi.org/10.1525/9780520918733-003.

Kabakova, Galina 2001. Otets i povitukha v rodil'noi obriadnosti Poles'ia. [Father and Midwife in the Birth Rites of the Polesie Region.] In: Ekaterina Belousova \& Sergei Nekliudov (eds.) Rodiny, deti, povitukhi v traditsiiakh narodnoi kul'tury. Moscow: Rossiiskii gosudarstvennyi gumanitarnyi universitet, pp. 107-129. Available at https://www.booksite.ru/fulltext/rodiny/text.pdf, last accessed on 22 September 2020.

Kabakova, Galina 2009a. Posled. [Placenta.] In: Nikita Tolstoi (ed.) Slavianskie dreunosti: etnolingvisticheskii slovar'. Vol. 4. Moscow: Mezhdunarodnye otnosheniia, pp. 200-202.

Kabakova, Galina 2009b. Povitukha. [Midwife.] In: Nikita Tolstoi (ed.) Slavianskie drevnosti: etnolingvisticheskii slovar'. Vol. 4. Moscow: Mezhdunarodnye otnosheniia, pp. 82-84. 
Krasovski, Aksiniia 2001. Obriady, obychai i verovaniia russkikh lipovan, sviazannye s rozhdeniem i kreshcheniem. [Rites, Customs and Beliefs of Russian Lipovans Concerning Birth and Christening.] In: Andrei Ivanov \& Svetlana Moldovan \& Angara Niri (eds.) Kul'tura russkikh staroobriadtsev $v$ natsional'nom i mezhdunarodnom kontekste. [Culture of Russian Old Believers in National and International Context.] Vol. 3. Bucharest: Kriterion, pp. 250-256.

Lefèber, Yvonne \& Voorhoever, Henk 1997. Practices and Beliefs of Traditional Birth Attendants: Lessons for Obstetrics in the North? Tropical Medicine and International Health, Vol. 2, No. 12, pp. 1175-1179. https://doi. org/10.1046/j.1365-3156.1997.d01-219.x.

Listova, Tatiana 1997. Obriady i obychai, sviazannye s rozhdeniem detei: Pervyi god zhizni. [Customs and Rituals Associated with the Birth of Children: The First Year of Life.] In: Vadim Aleksandrov \& Irina Vlasova \& Ninel' Polishchuk (eds.) Russkie. Moscow: Nauka, pp. 499-516. Available at https://www.booksite.ru/ fulltext/rus/sian/231.htm, last accessed on 22 September 2020.

Litvina, Natalia 2018. Staroobriadcheskie obshchiny Respubliki Moldova. [Old Believer Communities in the Republic of Moldova.] Pomorskii Sever, 20 November. Available at https://protopop-avvakum.ru/staroobryadcheskie-obshhinyrespubliki-moldova/, last accessed on 22 September 2020.

Naumescu, Vlad 2016. The End Times and the Near Future: The Ethical Engagements of Russian Old Believers in Romania. Journal of the Royal Anthropological Institute, Vol. 22, No. 2, pp. 314-331. http://dx.doi.org/10.1111/1467-9655.12379.

Oakley, Ann 1984. The Captured Womb: A History of the Medical Care of Pregnant Women. Oxford: Basil Blackwell.

Olson, Lora \& Adonieva, Svetlana 2016. Traditsiia, transgressiia, kompromiss: miry russkoi derevenskoi zhenshchiny. [Tradition, Transgression, Compromise: Worlds of a Russian Village Woman.] Moscow: Novoe literaturnoe obozrenie.

Plotnikova, Anna 2007. Chestvovanie povitukhi v russkikh selakh na Balkanakh. [Celebration in Honor of Midwife in Russian Villages in the Balkans.] In: Tatiana Nikolaeva (ed.) Terra Balkanica / Terra Slavica. K iubileiu T. V. Tsiv'ian. Balkanskie chteniia 9. Moscow: Institut slavianovedeniia rossiiskoi akademii nauk, pp. 113-117. Available at https://inslav.ru/images/stories/pdf/2007_ Balkanskie_chtenija_9_Terra_Balkanica_Terra_Slavica.pdf, last accessed on 22 September 2020.

Plotnikova, Anna 2016. Slavianskie ostrovnye arealy: arkhaika i innovatsii. [Slavic Island Areas: Archaism and Innovations.] Moscow: Institut slavianovedeniia rossiiskoi akademii nauk. Available at https://inslav.ru/sites/default/files/editions/2016_ plotnikova.pdf, last accessed on 22 September 2020.

Prygarine, Olexandre 2004. Les "vieux-croyants" (Lipovane) du delta du Danube. Ethnologie Française, Vol. 34, No. 2, pp. 259-266. Available at http://www. ethnologie-francaise.fr/numero/?numero=ETHN_042, last accessed on 22 September 2020.

Ransel, David L. 2000. Village Mothers: Three Generations of Change in Russia and Tataria. Bloomington \& Indianapolis: Indiana University Press.

Rouhier-Willoughby, Jeanmarie 2003. Birth Customs: Ancient Traditions in Modern Guise. The Slavic and East European Journal, Vol. 47, No. 2, pp. 227-250. http:// dx.doi.org/10.2307/3219945. 
Shchepanskaia, Tatiana 1994. Mir i mif materinstva. Sankt-Peterburg, 1990e gody. (Ocherki zhenskikh traditsii i fol'klora). [Maternity: Its World and Mythology (Feminine Traditions and Folklore in St. Petersburg of the 1990s.] Etnograficheskoe obozrenie, No. 5, pp. 15-27. Available at http://journal.iea.ras.ru/ archive/1990s/1994/no5/Schepanskaya_1994_5.pdf, last accessed on 22 September 2020.

Stoianova, Galina \& Trotsyk, Alla 2006. Spetsifika poslerodovogo tsikla u lipovan. [Specificity of the Postnatal Ritual Cycle among Lipovans.] Lipovane: istoriia i kul'tura russkikh staroobriadtsev, Vol. 3, pp. 151-154. Available at http://oldbelivers.com/ download.php?id=29910462, last accessed on 22 September 2020.

Trotsyk, Alla 2005. Povitukha v staroobriadcheskoi obshchine na Dunae. [Midwife in an Old Believer Community on the Danube.] Lipovane: istoriia i kul'tura russkikh staroobriadtsev, Vol. 2, pp. 155-156. Available at https://samstar-biblio.ucoz.ru/ publ/132-1-0-573, last accessed on 22 September 2020.

Tudose, Pavel 2015. Ruşii lipoveni din România - istorie şi actualitate. Comunitatea ruşilor lipoveni din Brăila - model de conviețire multietnică în context național şi European. [Russian Lipovans from Romania - History and Contemporaneity. The Community of Russian Lipovans from Braila - a Model of Multiethnic Cohabitation in National and European Context.] Bucharest: Editura C.R.L.R.

Uzeneva, Elena 2008. Obriady semeinogo tsikla staroverov Bolgarii. [Family Cycle Rites of the Old Believers of Bulgaria.] In: Leonid Kasatkin (ed.) Russkie staroobriadtsy: iazyk, kul'tura, istoriia: sbornik statei $k$ XIV Mezhdunarodnomu s"ezdu slavistov. Moscow: Iazyki slavianskikh kul'tur, pp. 171-183.

Vlaskina, Tatiana 2009. Osnovnye kharakteristiki kul'tury materinstva i detstva u kazakov-nekrasovtsev. [The Main Categories of the Nekrasov Cossacks' Culture of Motherhood \& Childhood.] Vestnik Iuzhnogo nauchnogo tsentra RAN, Vol. 5, No. 3, pp. 69-75. Available at http://www.ssc-ras.ru/files/files/Vectnik_UNZ_3_ Vlaskina_69-75_.pdf, last accessed on 22 September 2020.

Zakharchenko, Galina 2004. Ritualy, soprovozhdaiushchie rozhdenie detei v lipovanskoi traditsionnoi kul'ture Pridunav'ia. [Rituals of Child Birthing in the Lipovan Traditional Culture of the Danube Area.] Lipovane: istoriia i kul'tura russkikh staroobriadtsev, Vol. 1, pp. 115-118. Available at http://oldbelivers.com/content. php?page=etzncgmj_rus\&id=20, last accessed on 6 October 2020 .

Zakharchenko, Galina \& Petrova, Elena 2005. Pervyi god zhizni v narodno-religioznoi praktike lipovan. [The First Year of Life in Folk and Religious Practice of Lipovans.] Lipovane: istoriia i kul'tura russkikh staroobriadtsev, Vol. 2, pp. 157160. Available at http://oldbelivers.com/content.php?page=etzncgmj_rus\&id=20, last accessed on 22 September 2020.

Natalia Dushakova $(\mathrm{PhD})$ is a Research Fellow at the Russian Presidential Academy of National Economy and Public Administration, Moscow (Russia). She is a member of the Commission for the Studies of Old Believers at the International Committee for Slavic Studies. Her main research areas are anthropology of religion and memory studies. Since 2008 she has been conducting field research in Old Believer communities in the north-west Black Sea region.

nataliadusacova@gmail.com 